\title{
Thermosensitive Production of Their Transfer Systems by Group S Plasmids
}

\author{
By V. RODRIGUEZ-LEMOINE, * A. E. JACOB, R. W. HEDGES \\ AND NAOMI DATTA \\ Bacteriology Department, Royal Postgraduate Medical School, \\ London WI 2 oHS
}

(Received I9 June I974; revised I5 July 1974)

SUMMARY

Transfer of plasmids of group $\mathrm{S}$ is much more efficient at low temperatures (e.g. $22^{\circ} \mathrm{C}$ ) than at $37^{\circ} \mathrm{C}$. This is due to failure of the donor strain to produce the transfer system during growth at the higher temperature.

\section{INTRODUCTION}

A new class of transmissible plasmids has been identified in strains of Serratia marcescens. The plasmids constitute the compatibility class S (Hedges, Rodriguez-Lemoine \& Datta, 1975).

They were transferred from wild-type $S$. marcescens isolates into strains of $E$. coli $\mathrm{K} 12$ by conjugation. There was little or no transfer of these plasmids between strains of $E$. coli KI 2 when incubation was at $37{ }^{\circ} \mathrm{C}$. When, however, the incubation was at a lower temperature transfer proceeded at a much higher rate. We describe the identification of the temperaturesensitive step in the mating process.

\section{METHODS}

Bacteria. Both strains used in these experiments were nutritionally distinguishable derivatives of $E$. coli $\mathrm{KI} 2$. They were $\mathrm{J} 53\left(\mathrm{~F}^{-}\right.$, pro, met $)$and $\mathrm{J} 62.2\left(\mathrm{~F}^{-}\right.$, pro, his, trp, lac, rif).

Plasmids. R477 is an R factor of group S which determines resistance to streptomycin, tetracycline, chloramphenicol, kanamycin and sulphonamides. It and other $\mathrm{S}$ plasmids were described by Hedges et al. (1975).

Temperature shift experiments. The donor culture, J62.2(R477), was grown overnight in nutrient broth at $37^{\circ} \mathrm{C}$. It was diluted, usually $\mathrm{I}: \mathrm{I00}$, in nutrient broth and incubated at the desired temperature for at least $2 \mathrm{~h}$. Cultures were diluted with fresh broth at appropriate intervals in order to maintain the cell concentration at approximately $10^{8} \mathrm{cells} / \mathrm{ml}$, as measured by a Celloscope 302 particle counter (Lars Ljungberg and Co., Stockholm, Sweden).

After preliminary experiments, which showed that the conditions under which the recipient culture was grown before mating had little effect on the efficiency of transfer, recipient cultures were routinely grown to a concentration of approximately $10^{9} \mathrm{cells} / \mathrm{ml}$ at the temperature to be used during conjugation.

Mating mixtures were set up by mixing $4.5 \mathrm{ml}$ of the recipient culture with $0.5 \mathrm{ml}$ of the donor culture and adding to this mixture $5 \mathrm{ml}$ of fresh, pre-warmed broth. Mating mixtures

* Present address: Microbiology Department, University College, London W.C. I. 


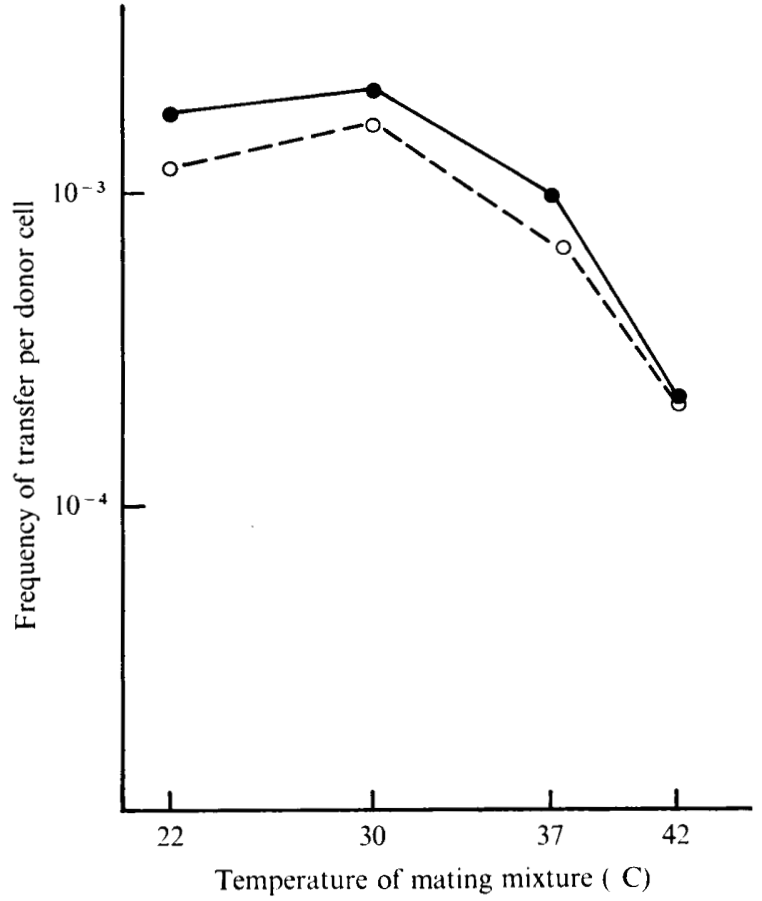

Fig. I

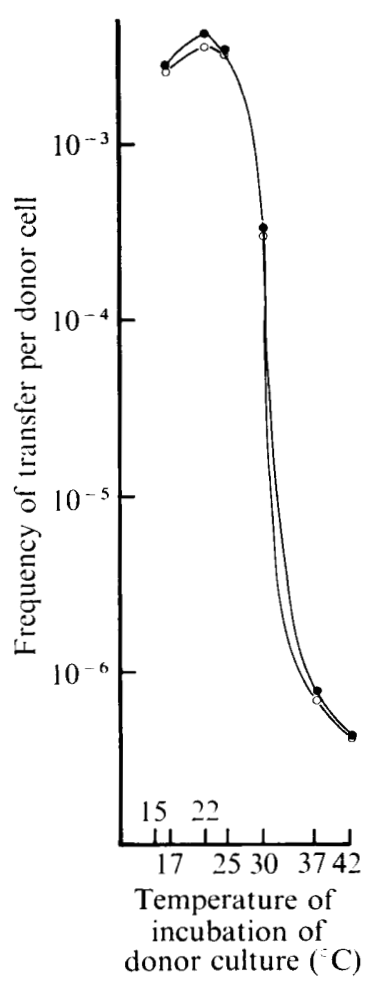

Fig. 2

Fig. I. The influence of the temperature of mating mixtures on transfer of R477. The donor culture, $\mathrm{J} 62-2(\mathrm{R} 477)$, was grown unshaken at $22^{\circ} \mathrm{C}$. 9 , Selection for tetracycline resistance; $\mathrm{O}$, selection for kanamycin resistance.

Fig. 2. The influence of the temperature at which the donor culture was incubated before mating. All mating mixtures were incubated at $22^{\circ} \mathrm{C}$. Donor cultures were adjusted to uniform density before mating. For symbols, see Fig. I.

were incubated at an appropriate temperature for $\mathbf{I} \mathbf{h}$, after which suitable dilutions were spread on selective agar plates.

Stability of inheritance. The stability of S plasmids at various temperatures was tested as described by Coetzee, Datta \& Hedges (I972).

\section{RESULTS}

\section{Temperature shift experiments}

R477 was the representative S plasmid used in these experiments, which showed that it was the temperature of incubation of the donor culture before mating which determined the efficiency of transfer. If the donor was preincubated at $22{ }^{\circ} \mathrm{C}$ the mating proceeded efficiently; the temperature at which the mating mixture was incubated was of little significance (Fig. I).

Figure 2 shows the effect of preincubation of the donor cultures at various temperatures before mating at $22{ }^{\circ} \mathrm{C}$. Transfer efficiency was highest $\left(4 \times 10^{-3} /\right.$ donor cell) from the culture incubated at $22{ }^{\circ} \mathrm{C}$. The frequency of transfer from the culture incubated at $37^{\circ} \mathrm{C}$ was about 5000 -fold less $\left(7 \times \mathrm{IO}^{-7} /\right.$ donor cell). 


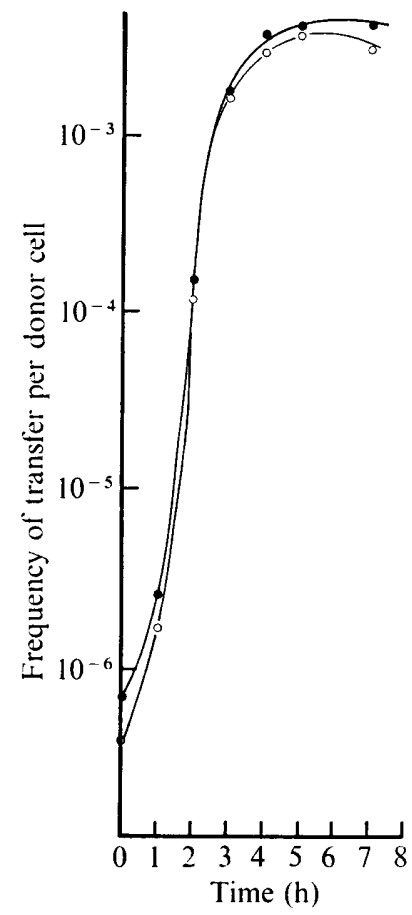

Fig. 3

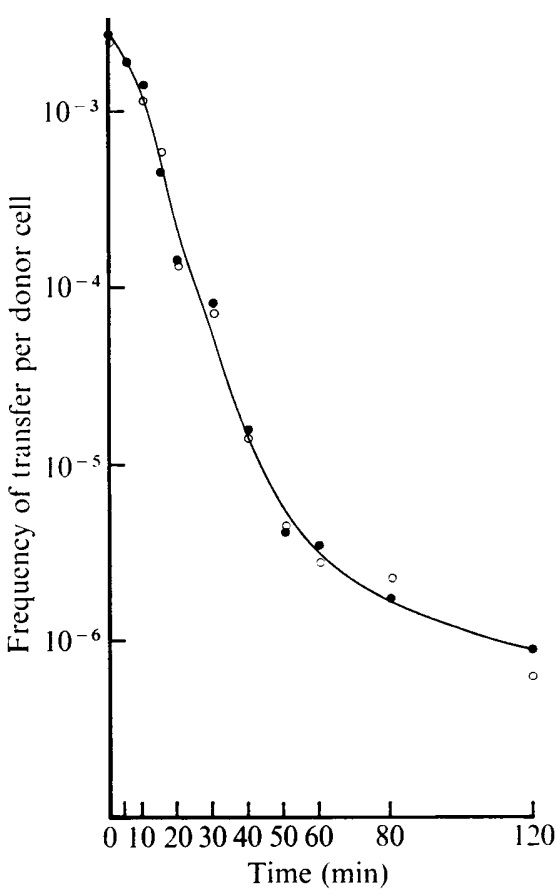

Fig. 4

Fig. 3. Acquisition of mating ability at low temperature. The donor culture was grown at $37^{\circ} \mathrm{C}$, and diluted into broth at $22{ }^{\circ} \mathrm{C}$ at time 0 . At intervals, matings were made at $22{ }^{\circ} \mathrm{C}$. For symbols, see Fig. I.

Fig. 4. Loss of mating ability at high temperature. The donor culture was grown at $22{ }^{\circ} \mathrm{C}$, and diluted into prewarmed broth at $37^{\circ} \mathrm{C}$ at time 0 . At intervals, matings were made at $22{ }^{\circ} \mathrm{C}$. For symbols, see Fig. I.

Figure 3 shows the regeneration of conjugative ability when a donor culture, in log phase, was transferred from 37 to $22{ }^{\circ} \mathrm{C}$. Complete recovery of activity took place within $4 \mathrm{~h}$.

Figure 4 shows the kinetics of loss of conjugative ability when a donor culture in $\log$ phase was transferred from 22 to $37^{\circ} \mathrm{C}$. Within $\mathrm{I}$ h, transfer ability fell approximately Iooo-fold.

S plasmids from different sources and with different resistance patterns, R478, R826 and R829 (Hedges et al. 1975), were all transferred more efficiently between strains of $E$. coli KI 2 when the donor cultures were grown at low temperature.

Stability of $S$ plasmids during vegetative growth

The inheritance of plasmids of group S was stable at both 30 and $43{ }^{\circ} \mathrm{C}$.

\section{DISCUSSION}

The temperature dependance of plasmid transfer has been previously studied with matings mediated by the F factor and by RtsI. F matings are efficient over a considerable range of temperature (Wood, 1968). Conjugation takes place with high efficiency at $37^{\circ} \mathrm{C}$ and markedly less efficiently at $22{ }^{\circ} \mathrm{C}$. Transfer of Rts I occurs with very low efficiency at $37^{\circ} \mathrm{C}$ and is 
much more effective at $30{ }^{\circ} \mathrm{C}$ or below. This low efficiency of transfer at high temperature is associated with a failure to replicate at such temperatures (Terawaki, Takayasu \& Akiba, I967; Coetzee et al. 1972). S plasmids, however, are able to replicate efficiently in E. coli $\mathrm{KI} 2$ growing at high temperatures. Also, Rts I ${ }^{+}$cultures of $E$. coli grow poorly at $37^{\circ} \mathrm{C}$ or above (Terawaki, Kakizawa, Takayasu \& Yoshikawa, 1968; Di Joseph, Bayer \& Kaji, 1973). Strains carrying $\mathrm{S}$ plasmids showed no such abnormalities of growth. As will be discussed, the inefficient transfer of $\mathrm{S}$ plasmids at high temperatures results from a failure to synthesize a transfer system rather than a failure of DNA replication. Thus, the mechanisms underlying the thermolability of plasmid transfer are quite different.

The results of the temperature-shift experiments show that a prolonged period of incubation at low temperature is required if a strain of $E$. coli carrying an $S$ plasmid is to acquire the ability to transfer the plasmid. The ability can be expressed at high or low temperature, but if a culture capable of transfer is incubated at $37{ }^{\circ} \mathrm{C}$ the ability is progressively lost.

We conclude that at low temperature, the plasmid is able to determine the synthesis of a transfer system that is capable of functioning at 22 or $37^{\circ} \mathrm{C}$, but that at the latter temperature, de novo synthesis of one or more components of this system is inhibited.

Since $\mathrm{S}$ plasmids seem to be adapted to transfer at temperatures lower than mammalian body temperature and their only known natural host ( $S$. marcescens) is often found in soil and water, it is natural to postulate that the $S$ plasmids evolved in Serratia populations in environments where low temperatures are usual.

The fact that all the Serratia $\mathrm{R}$ factors came from strains isolated from human infections (Hedges et al. 1975) may imply that genes for antibiotic resistance of advantage in the hospital environment have become associated with plasmids evolved in response to different evolutionary pressures.

V.R.-L. was supported by the Consejo de Desarrollo, Científico y Humanístico, Universidad Central de Venezuela. N.D. was in receipt of a grant from the Medical Research Council.

\section{REFERENCES}

Coetzee, J. N., Datta, N. \& Hedges, R. W. (1972). R factors from Proteus rettgeri. Journal of General Microbiology 72, 543-552.

Di Joseph, C. G., BAYER, M. E. \& KaJI, A. (1973). Host cell growth in the presence of the thermosensitive drug resistance factor, Rts I. Journal of Bacteriology 115, 399-4IO.

Hedges, R. W., Rodriguez-Lemoine, V. \& DatTA, N. (I975). R factors from Serratia marcescens. Journal of General Microbiology 86, 88-92.

Terawaki, Y., Kakizawa, Y., Takayasu, H. \& Yoshikawa, M. (i968). Temperature sensitivity of cell growth in Escherichia coli associated with the temperature sensitive R(KM) factor. Nature, London 219, $284-285$.

Terawaki, Y., Takayasu, H. \& Akiba, T. (1967). Thermosensitive replication of a kanamycin resistance factor. Journal of Bacteriology 94, 687-690.

Wood, T. H. (1968). Effects of temperature, agitation and donor strain on chromosome transfer in Escherichia coli K1 2. Journal of Bacteriology 96, 2077-2084. 